\title{
CHANGES OF AGRICULTURAL LANDSCAPE PATTERN - NON-NATURAL DRIVING FORCES ANALYZING BASED ON THE NORTH-WESTERN REGION OF POLAND
}

\author{
IWONA MARKUSZEWSKA \\ Institute of Physical Geography and Environmental Planning, Adam Mickiewicz University, Poznań, Poland
}

Manuscript received: September 26, 2012

Revised version: January 21, 2013

\begin{abstract}
MARKUSZEWSKA I., 2013. Changes of agricultural landscape pattern - non-natural driving forces analyzing based on the North-Western Region of Poland. Quaestiones Geographicae 32(1), Bogucki Wydawnictwo Naukowe, Poznań, pp. 5-14. 4 tables, 2 figs. DOI 10.2478/quageo-2013-0001, ISSN 0137-477X.

АвSTRACT. In this paper, preceding changes and current situation in agricultural landscape pattern were elaborated as well as future transition was discussed. The North-Western Region of Poland was chosen as a study area, however, the research was conducted at the regional level, in provinces of this region including: Lubuskie, Wielkopolskie and Zachodniomomorskie. For analysis statistical data from Common Agricultural Census, containing the last two decades, between 1990-2010, were extracted. Based on established knowledge and proposed approach driving forces of landscape changes were identified. The research deals with the following aspects: 1 ) identification of underlying trends of landscape changes that took place over the study period, 2) finding driving forces responsible for cause-effect relationships in landscape alteration, 3) recognition of farmers' reasons for what they took actions leading to landscape changes, and 4) identification of major current and foreseeable future tendencies of modification of landscape pattern. Political, economic and social driving forces, as the most affecting, were recognized and their influence on agricultural landscape structure was analyzed.
\end{abstract}

KEY WORDS: agricultural landscape pattern, changes, non-natural factors

Iwona Markuszewska, Institute of Physical Geography and Environmental Planning, Adam Mickiewicz University, ul. Dzięgielowa 27, 61-680 Poznań, Poland, e-mail: iwmark@amu.edu.pl

\section{Introduction}

Agrarian areas are under constant human pressure, where farmers play crucial roles in landscape shaping. Transformation of spatial composition of individual landscape elements and their arrangement is the foremost visible result of anthropogenic influence, what had been emphasized in many studies before (e.g. Naveh \& Lieberman 1984; Ryszkowski 2002). The agricultural landscape patterns within European countries had been changed intensively over the last decades, however, at the regional level specific mechanisms and different transition dynamics as well as various driving factors responsible for it can be recognized (Brandt et. al 1999, Vos \& Meekes 1999, Klijn 2006, Reger et al. 2007, Antrop \& van Eetwelde 2008). The knowledge about the key factors bringing about major changes in landscape is vital to decision-making process concerning spatial planning (Marcucci 2000). Moreover, very important is also the conscious- 
ness of consequences of driving factors influence on landscape, because it can avoid occurring of adverse transition or inadvisable disturbance (Nilsson 2004).

Referring to the Polish case, it should be emphasized that the last two decades was a phase of radical reforms in agriculture as an economic sector, where two transition turning points can be distinguished. The first one, after 1989, was a result of communism collapse, when a centrally planned economy was replaced with a market economy that radical restructure was associated with. The second one was associated with Polish accession to the European Union, in 2004, and in a consequence of that the implementation of obligatory guidelines of the Common Agricultural Policy. Owing to this, the changeovers led to both, constructive and harmful outcomes, related to social, environmental and economic issues, what undoubtedly, in an important way, reflected in modification of agricultural landscape pattern.

In light of these findings, the influence of non-natural factors on changes of agricultural landscape was investigated. The study, covering the last two decades, from 1990 to 2010, was focused on the North-Western Region of Poland and based on statistic derived from the Common Agricultural Census Data. The research deals with the following aspects: 1) identification of underlying trends of landscape changes that took place over the study period, 2) finding driving forces responsible for cause-effect relationships in landscape alteration, 3) recognition of farmers reasons for what they took actions leading to landscape changes, and 4) identification of major current and foreseeable future tendencies of modification of landscape pattern.

\section{Data and methods}

Taking into account the methodological approach, put forward for consideration in this paper, the agricultural landscape pattern is understood as a diversity of landscape elements occurring in a certain space, changeable over time as a result of non-natural factors pressure. According to this interpretation, within the study area three main dimensions were distinguished:
1) agrarian structure, 2) agricultural land use, and 3) crop rotation. The aim of that structural landscape splitting was to draw the attention on both, relatively stable and rapidly changeable over time, agrarian use units, namely fields, plots, parcels, etc.

According to the Statistical Yearbook of Agriculture (2011) agrarian structure is defined as the characterization of agrarian production units, classified by: land ownership, farm size and farmland fragmentation. Agricultural land use includes: arable land, orchards and permanent grasslands (meadows and pastures), whereas crop rotation contents, inter alia, basic cereals, industrial plants and feed plants.

One of the specific features of Polish agrarian structure, worth drawing the attention on, is farmland fragmentation. The farmland fragmentation, so-called patchwork, means that fields are split up into a large number of tiny plots scattered between varied landowners with a difficult arrangement to farming. The fragmentation, described by plots distribution pattern, relates to: small average size of a farm (7 ha), relatively high number of land plots per one farm (8 pieces), and small average size of the individual plot (0.6 ha). Additionally, the distance between the farm and cultivated fields is considerably remote, sometimes reaching up to 3 and even $4 \mathrm{~km}$ (Woch 2006). In spite of the fact that this economically inconvenient patchwork cause a strong cultivation problem, from the ecological point of view this type of fields arrangement is very favorable. It is especially important when the landscape diversity aspect is considered, what proves the statement: the greater fragmentation of farmland, the higher saturation of landscape elements (Ryszkowski 2002), what in another way means that this type of landscape is more resistant to influence of adverse external factors. Moreover, it is worth mentioning that fragmentation of agricultural land leads to the increase of landscape diversity, what is proving by a great number of balks, paths, drainage ditches, shelterbelts as well as linear shrubs along ditches and balks.

As it has been said before, the agrarian area is primarily designed by farmers participating actively in a process of landscape shaping, for example, decision of spatial and temporal dimensions of crops allocation allows to shape a new 
spatial pattern coherent with land-use dynamic (Schaller et. al 2012). Cultivated plants have a major impact on creation of spatial mosaic what is visible by crop succession during the growing season, however, it is just a slight pattern modification. Much more destructive influence, including destroying land heterogeneity, can be observed when policulture rotation system is replaced with intensively used monoculture. Also the type of agricultural land use shapes spatial diversity, twofold: in temporarily way, when for instance, farmland is provisionally abandoned due to lack of profitability of farming, or in permanent way, when area is afforested as a result of establishing of new trees or orchards plantations. In this manner land-use mosaic and crops distribution pattern modify landscape diversity.

The theoretical line of thinking is illustrated in figure 1. The basic point of framework approach building was the recent statistical data collection, used in analyzing of changes of landscape structure, but also in recognition of past transition trends. On the other hand, the knowledge of the identified driving forces responsible for that al- teration was served for drawing possible future tendencies of landscape transition.

In regards to a very intensive period of economic transition in Poland the last two decades were taken into account. For quantitative analysis the data of Central Statistical Office, available at the Local Data Bank, were used, together with: Statistical Yearbooks of Agriculture, between 1990-2010, and Common Agricultural Census data, years: 1996, 2002, 2010.

So that the suggested purposes could be set in motion, the study was suit to regional level. It was necessary, because only in this way it was possible to recognize the main trends of landscape changes and to compare the investigation results between all provinces, as sub-regional units within the analyzed area. Moreover, the results of field study revealed that local trends do not always prove the main directions of changes, which are so characteristic for regional stage. Another arguments for are historical events which in significant ways influenced on differences in agriculture development, possible to recognize only at the regional scale.

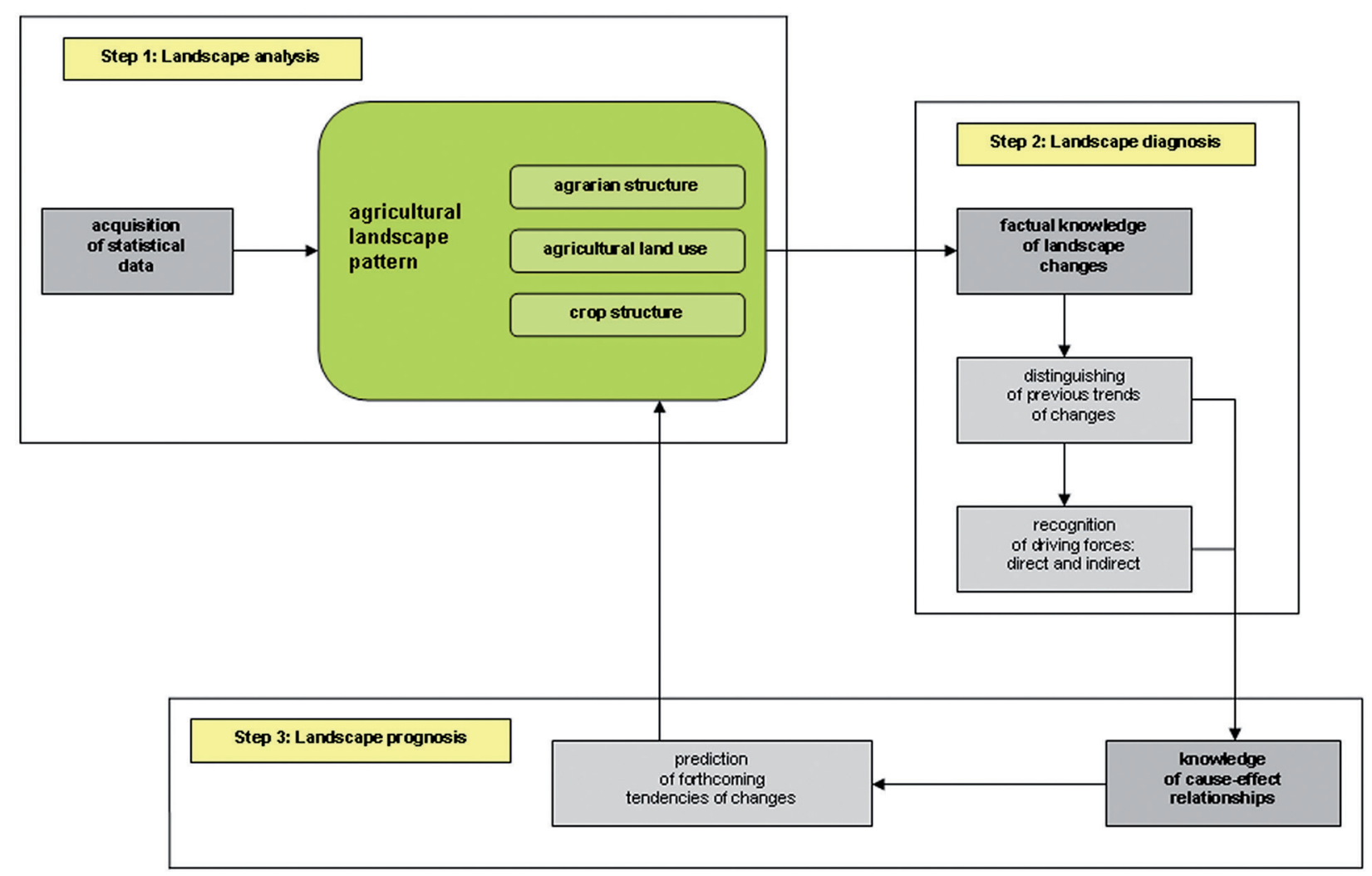

Fig. 1. Framework of methodological approach. 


\section{Study area}

As a study area the North-Western Region was chosen (Fig. 2). It should be explained that the name of the region was taken from the NUTS nomenclature, which is applied in the process of collection and data sharing of regional statistics of the European Union countries (Bański \& Czapiewski 2007). Although the study was focused on the North-Western Region, the research was conducted at the regional level, in provinces including: Lubuskie, Wielkopolskie and Zachodniomomorskie.

This region was selected on purpose, due to specific and dissimilar historical, economic and social conditions, which effects can be distinguish in: 1) spatial differentiation of agriculture development intensification, because coexist here both, intensive and extensive farming, 2) different level of production effectiveness, because there are market oriented farms as well as self-sufficient family farms, 3) different landownership, because except dominating private holdings it also can be found farmland belonged to the Agency of Agricultural Property. All these above reflect on arrangement of spatial farmland, evidently visible in a variety of mosaic of agrarian used parcels, where small-size fields create

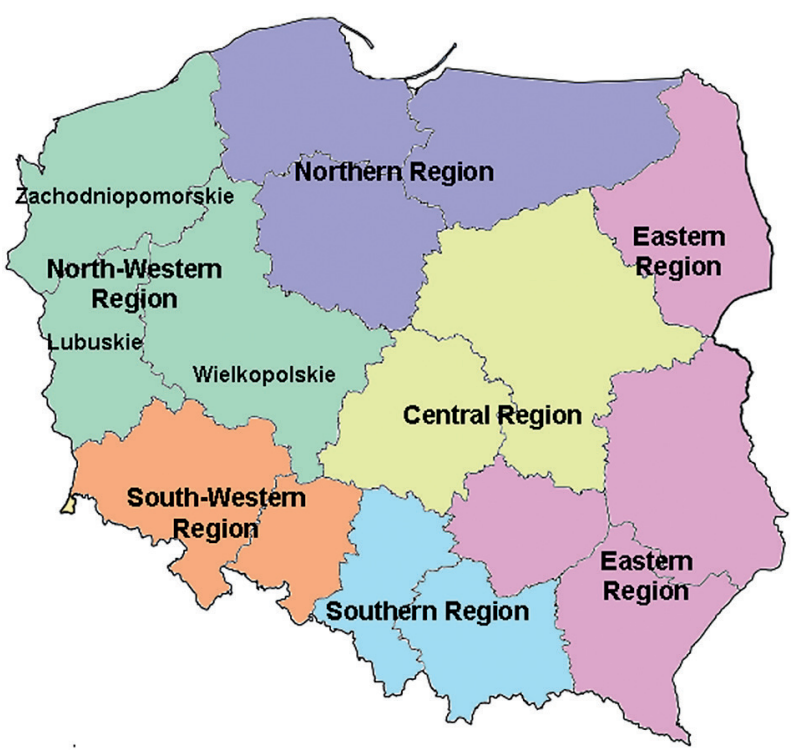

Fig. 2. Location of the study area, North-Western Region divided into the provinces, against a background of other regions determined in accordance with Nomenclature of Units for Territorial Statistics (NUTS), level 1. policultures and, in opposite, large-scale fields monocultures.

Among analyzed provinces, Wielkopolskie stands out from the others in terms of long good agricultural tradition. Taking into account only the postwar period, private farmland ownership dominated here, however, average farm size was relatively small, less than 10 ha $^{1}$ (Markuszewska 2012). Here small scale farming is a matter of agriculture and its role is invaluable, what explain two reasons: 1) farming activity is the only source of incomes in family farms, and 2) farmland has a special value for farmer, because it is inherited from generations. Moreover, family farms are self-sufficient and only the commodities surplus are designed for sale.

On the other hand, Lubuskie and Zachodniopomorskie provinces, the others included in the analyzed Region, do not have such as a great agricultural experiences. After 1945, they belonged mostly to the Regained Territories, where within nationalized land being formerly German estate, State Agriculture Farms were created. As for the farm size, they covered considerable surface, exceeded more than 1000 ha (Czapiewska 2003). As a result of economic transition, at the beginning of the 1990s, external government financial support was suspended, leading to state farms' bankruptcy. In that situation, agricultural land was partly purchased or rented by private owners, while the remaining farmland was managed by the State Treasury Land Property Agency (since 2003, the Agency of Agricultural Property).

As confirmation of the mentioned facts, there are statistics on the share of agricultural land in the total area. For Wielkopolskie, the share is the largest, about 65\% (1.950 million ha), for zachodniopomorskie - 49\% (1.130 million ha), while in lubuskie - 41\% (571 thousand ha) (Statistical Yearbook of Agriculture 2011).

The natural condition of agricultural development, expressed by the assessment of natural

1 It is worth to note that the predominance of private farmland ownership during the socialist era, where officially the whole nationalized land belonged to the state, was in Poland, as a country of the Eastern Block, something phenomenal. 
condition for agricultural production ${ }^{2}$, in individual districts (next to communes another local administrative division units) ranges from 55 to 75 points; compared with national average 66,6 points (Kołodziejczak 2010).

\section{Results and discussion}

\subsection{Changes of agrarian structure}

The huge interest in changes of agrarian structure was focused on characterization of plot distribution pattern, but especially on aspects relating to farms' acreage and holdings' amount.

One has to be recognized that over the last few years farm size had been increasing systematically, predominantly in Zachodniopomorskie (Table 1). Also, here the largest area of private farms occurred, oscillating around on average $23 \mathrm{ha}$, however, the largest holdings occupied more than 1,000 ha. Moreover, in Zachodniopomorskie the percentage share of relatively large farms, which means over 50 ha, is here the highest (Table 2). In contrast, in Lubuskie and Wielkopolskie, average area of family farms is considerably smaller, 10.5 ha and 11 ha respectively, yet it is still larger than national average ( $6.8 \mathrm{ha})$. Steadily decline of the smallest-size, under $5 \mathrm{ha}$, and simultaneously increase of large-scale, a tendency particularly seen since 2002, is a positively assessed change. Nevertheless, still the smallest husbandries dominate, which in each provinces account for more than $50 \%$ of the total number, and unfortunately, the growing trend is not so spectacular as it would be expected.

Looking for the factors initiated above changes, it goes without saying that at the beginning of the 1990s economic transition was a driving force. Adaptation to new market economy mechanisms with many adverse consequences was connected, among which the following two were the most important: 1) dissolution of State Agricultural Farms, and 2) collapse of unprofitable small-scale private family farms. In regards to the first one, agrarian land had been re-developed

2 This indicator, developed by the Institute of Soil Science and Plant Cultivation in Puławy, by numerical values determines quality of soil, climate, terrain and water condition. by purchasing or tenanting previously parceled out huge-size plots, however, the large size of fields was kept, what resulted in maintenance of monoculture landscape mosaic. What is also important, the changeover made individual private investors (social factor) more active, what was manifested by intensifying interest in farmland purchasing. In respect to the latter, farmland of small private farms was sold and in this way other holdings were expanded. Owing to this, a relatively stable agrarian structure was observed in Wielkopolskie. This is due to constant private farmland ownership as well as a stable fields' arrangement, in contrary to Zachodniopomorskie and Lubuskie, where significant share of agricultural land used to be managed by the state.

Referring to the aspect of growing acreage of farms, it is worth to note that this process is really desirable for both, simplifying of mechanization work and boost of production efficiency, because what has been estimated (Woch 2006, Wierzchnowski 2007), the most troublesome feature of patchwork is considerable distance between farmstead and fields, what generates transport, labor and production costs, rising proportionally to the length increase. As was previously stated, the farms' acreage is going up. However, detailed analysis carried out at the landscape level, is not so unambiguous as shown the data, because field research revealed that it is not a result of land consolidation, which would be the most appropriate activity for adequate farmland arrangement. In contrast, new plots of arable land, non-neighboring with property boundaries, are purchasing, what in fact leads to increase of fields fragmentation. Nevertheless, the current landscape pattern from the ecological point of view is recommended to preserve landscape diversity. In this case, agrarian land is enriched with a large number of mid-field balks, fulfilling their practical roles as farmland property boundaries. What is also

Table 1. The average acreage of farms in provinces of the North-Western Region prepared on the data from

Agricultural Census Data, years: 1996, 2002, 2010

(in ha).

\begin{tabular}{|l|r|r|r|}
\hline \multirow{2}{*}{ Provinces } & \multicolumn{3}{|c|}{ Years } \\
\cline { 2 - 4 } & $\mathbf{1 9 9 6}$ & $\mathbf{2 0 0 2}$ & $\mathbf{2 0 1 0}$ \\
\hline Lubuskie & 7.8 & 8.8 & 14.1 \\
\hline Wielkopolskie & 8.8 & 9.9 & 12.5 \\
\hline Zachodniopomorskie & 14.2 & 14.7 & 23.1 \\
\hline
\end{tabular}


Table 2. Changes in farms' number according to the size range in provinces of the North-Western Region prepared on the data from Agricultural Census Data, years: 1996, 2002, 2010.

\begin{tabular}{|c|c|c|c|c|c|c|c|c|c|c|c|c|c|}
\hline \multirow{3}{*}{ Provinces } & & \multicolumn{12}{|c|}{ Years } \\
\hline & & \multicolumn{4}{|c|}{1996} & \multicolumn{4}{|c|}{2002} & \multicolumn{4}{|c|}{2010} \\
\hline & & Total & $\begin{array}{l}>5 \\
\text { ha }\end{array}$ & $\begin{array}{c}5-50 \\
\text { ha }\end{array}$ & $\begin{array}{l}<50 \\
\text { ha }\end{array}$ & Total & $\begin{array}{l}>5 \\
\text { ha }\end{array}$ & $\begin{array}{c}5-50 \\
\text { ha }\end{array}$ & $\begin{array}{l}<50 \\
\text { ha }\end{array}$ & Total & $\begin{array}{l}>5 \\
\text { ha }\end{array}$ & $\begin{array}{c}5-50 \\
\text { ha }\end{array}$ & $\begin{array}{l}<50 \\
\text { ha }\end{array}$ \\
\hline \multirow{2}{*}{ Lubuskie } & In thousends & 28.7 & 15.9 & 12.2 & 0.5 & 55.4 & 43.6 & 10.9 & 0.9 & 43 & 31.8 & 9.8 & 1.4 \\
\hline & In percent* & 100 & 55.6 & 42.6 & 1.8 & 100 & 78.7 & 19.7 & 1.6 & 100 & 74.9 & 22.9 & 3.2 \\
\hline \multirow{2}{*}{ Wielkopolskie } & In thousends & 151 & 60.8 & 89.2 & 1 & 202.1 & 120.1 & 79.4 & 2.6 & 162.7 & 86.3 & 72.8 & 3.5 \\
\hline & In percent * & 100 & 40.2 & 59.1 & 0.7 & 100 & 59.4 & 39.3 & 1.3 & 100 & 53 & 44.5 & 2.2 \\
\hline \multirow{2}{*}{$\begin{array}{l}\text { Zachodniopo- } \\
\text { morskie }\end{array}$} & In thousends & 73 & 50.2 & 21.1 & 1.7 & 71 & 50.1 & 18.6 & 2.4 & 48 & 29.2 & 15.7 & 3.1 \\
\hline & In percent * & 100 & 68.7 & 29 & 2.3 & 100 & 50.5 & 26.1 & 3.4 & 100 & 60.8 & 32.7 & 6.5 \\
\hline
\end{tabular}

\begin{tabular}{|c|c|c|c|c|c|c|c|c|c|}
\hline \multirow{2}{*}{ Provinces } & & \multicolumn{4}{|c|}{ Changes 1996-2002 } & \multicolumn{4}{|c|}{ Changes 2002-2010 } \\
\hline & & Total & $>5$ ha & 5-50 ha & $<50$ ha & Total & $>5$ ha & 5-50 ha & $<50$ ha \\
\hline \multirow{2}{*}{ Lubuskie } & In thousends & +26.7 & +27.7 & -1.3 & +0.4 & -12.4 & -11.8 & -1.1 & +0.5 \\
\hline & In percent* & +93.1 & +174.2 & -10.7 & +80.0 & -22.4 & -27.1 & -10.1 & +55.6 \\
\hline \multirow{2}{*}{ Wielkopolskie } & In thousends & +51.1 & +59.3 & -9.8 & +1.6 & -39.4 & -33.8 & -6.6 & +0.9 \\
\hline & In percent * & +33.8 & +97.5 & -10.9 & +160.0 & -19.5 & -28.1 & -8.3 & +34.6 \\
\hline \multirow{2}{*}{$\begin{array}{l}\text { Zachodniopo- } \\
\text { morskie }\end{array}$} & In thousends & -2.0 & -0.01 & -2.5 & +0.7 & -23.0 & -20.9 & -2.9 & +0.7 \\
\hline & In percent * & -2.7 & -0.01 & -11.8 & +41.2 & -32.4 & -41.7 & -15.6 & +29.2 \\
\hline
\end{tabular}

* - for individual years it means percentage share of the certain group of farms in the whole number; In changes it means percentage of changes.

worth to mention is that results of comprehensive land consolidation work, in opposite to traditional land merging, does not impoverish the landscape diversity. Although it is truth that the number of mid-fields balks is increasing, but simultaneously new shelterbelts or groups of trees, drainage ditches and other linear elements are introducing.

In a view of trends of agrarian structure changes, in the foreseeable future, any radical transition should be expected. Even within farms currently tenanted, it is not predictable, neither a total re-change of farmland ownership (that land still belongs to the Agency of Agricultural Property), nor an entire land parceling, because the demand for it is not recognized. Furthermore, land consolidation process, which could meaningfully modify the landscape structure, will not threaten of farmland arrangement due to the slowly going process, which is observed nowadays. There are a number of reasons for that. First of all, farmers are not aware the fact that this activity is set up on their own initiatives. Secondly, local actors responsible for land consolidation carrying (the Act on Land Consolidation) are not interested in promoting this idea among farmers. Finally, financial reserve for agriculture arrangement works is steadily decreasing. However, it is not excluded that influence of above factors will cause a local major modification of landscape pattern.

\subsection{Changes of agricultural land use}

Despite the fact that area under cultivation is meaningful, a noticeable downward share is observed as a de-farming process. De-farming means to obtain the permission of good quality farmland for non-agricultural purposes using, such as: building-up or establishing of communication infrastructure, because accordance with the law investing of agrarian areas spread over the high-quality soil is forbidden. Between 2000 and 2010 the decrease was respectively: in Zachodniopomorskie 6\% (69,800 ha), in Lubuskie $5 \%(25,000 \mathrm{ha})$, while in Wielkopolskie - 0.1\% (2,400 ha) (Yearbook Statistics of Agriculture 2011).

As for agricultural land use, arable land is the most important category. Regrettably, disturbingly considerable decrease in Zachodniopomorskie was observed, namely 94,000 ha, which is $11 \%$ of agricultural land. Although in Lubuskie the percentage share was higher, almost $15 \%$, the surface covered only 58,000 ha. In contrast, in Wielkopolskie the share of arable land felt to 43,500 ha, however, within the province it was only 3\% of farmland (Local Data Bank http:// www.stat.gov.pl/bdl). It should be pointed that decreasing share of arable land was a result of forested area growing in regards to afforesta- 
Table 3. Acreage of fallow fields in the selected years in provinces of the North-Western Region prepared on the data from Statistical Yearbooks of Agriculture (years: 1998, 2000, 2003, 2005, 2010).

\begin{tabular}{|l|l|c|c|c|c|c|}
\hline \multicolumn{2}{|c|}{ Provinces } & \multicolumn{5}{c|}{ Years } \\
\cline { 3 - 8 } & & $\mathbf{1 9 9 8}$ & $\mathbf{2 0 0 0}$ & $\mathbf{2 0 0 3}$ & $\mathbf{2 0 0 5}$ & $\mathbf{2 0 1 0}$ \\
\hline \multirow{2}{*}{ Lubuskie } & In thousends ha of fallow fields & 103.7 & 116.8 & 109.2 & 62.4 & 21.5 \\
\cline { 2 - 8 } & In percent of agricultural area & 19.7 & 21.3 & 23.6 & 13.0 & 4.8 \\
\hline \multirow{2}{*}{ Wielkopolskie } & In thousends ha of fallow fields & 68.6 & 82.4 & 64.2 & 37.1 & 25.5 \\
\cline { 2 - 8 } & In percent of agricultural area & 3.4 & 4.3 & 3.6 & 2.1 & 1.4 \\
\hline \multirow{2}{*}{ Zachodniopomorskie } & In thousends ha of fallow fields & 152.3 & 175.1 & 229.5 & 126 & 31.8 \\
\cline { 2 - 8 } & In percent of agricultural area & 14.0 & 15.8 & 22.1 & 12.7 & 3.3 \\
\hline
\end{tabular}

tion action on implementation of the Rural Areas Operation Programme for 2007-2013, according to activity: Afforestation of Agricultural and of Non-agricultural Land.

Over the study period significant fluctuation in orchards surface was observed: between 1996 and 2002 a clearly visible downward trend, which in the next period, 2002-2010, showed a dynamic growth. In Zachodniopomorskie the increase was the highest, of nearly $370 \%$ (from 4,500 to 21,000 ha), much less in Lubuskie (of 67\%, from 3,000 to 5,000 ha), while in Wielkopolskie only of $27 \%$ (growth from 16,500 to 23,000 ha) (Local Data Bank http://www.stat.gov.pl/bdl). Here, some financial support, as an agricultural policy roles implementation, was offered to farmers who established within their farms walnut plantations.

Furthermore, study revealed decreasing share of grassland, which is an evident failure symptom in intensive cattle breeding. In all provinces the decline oscillated around 58\%, however, the area was varied: the greatest importance in Zachodniopomorskie $(40,000 \mathrm{ha})$, a little lower in Wielkopolskie (33,000 ha), and the less in Lubuskie (16,000 ha) (Local Data Bank http://www. stat.gov.pl/bdl).

Bearing in mind all above study results, there is no doubt that the direct cause of agricultural land use change was implementation of agricultural policy guidelines (political factor) simultaneously with financial subsidies support (economic factor). The influence of these mechanisms, put into action through farmers (social factor), was manifested on landscape pattern changes, in two different ways.

On the one hand, by unprofitability or profitability of agrarian production, expressed initially, after 1989, by partial exclusion of arable land, and in later, after 2004, by again re-development of formerly abandoned area. It was concerned with set-aside issue what occurred at a massive scale at the beginning of the 1990s, after state or private farms' collapse (Table 3). That situation appeared especially in Zachodniopomorskie and Lubuskie provinces, where an essential farmland acreage was managed by the state sector or was characterized by unfavorable natural condition. After 2004 an enormous decrease in fallow fields share was noted thanks to EU financial subsidies for set-aside re-cultivating or maintaining them in extensive use. Contrary to it, Wielkopolskie was distinguished by the lowest share of abandoned land. In this case both, domination of private farmland ownership and elevated agrarian manner, inhibited from fallow fields widespreading, even within areas under unfavorable farming management.

On the other hand, this economic factor was expressed by financial support, according to specific ways of farming promotion, pursuant to the guidelines of state agricultural policy objectives, coherent with UE policy (political factor) (Programme of Rural Areas Development in 2007-2013, Strategy of Rural and Agriculture Areas Development in 2007-2013 with prognosis up to 2020). In this case, the permanent change of landscape structure was associated with treelined and wooded area increase.

In conclusion, policy directives were undoubtedly the driving forces leading to changes of agricultural land use structure. Fluctuating changes of agrarian policy objectives in reference to global demand as well as EU guidelines, in the coming years will probably cause the rebuild of agriculture land use. However, it is difficult to determine the direction of transition due to high volatility and unpredictability impact of these external factors. 


\subsection{Changes of crop rotation}

Table 4 contains statistics about the most important cultivated plants. Generally speaking, decreasing sown area as a result of lack of production profitability, contributed to set-aside which major surface of them was abolished after 2004, as written above. Moreover, the observed tendencies revealed that main crop planting was gradually adjusted diversiform cultivation.

In regards to sown area under basic cereals, except Lubuskie, the surface had been decreasing considerably, especially up to 2002, due to a declining number of households engaged in crop production. Within cereals the most important are wheat and maize, so-called as intensive crops, which indicate the level of production intensity. There is a believe that the larger share of intensive crop in the total sown area, the more intensive plant production. Regarding to it, only in Lubuskie positive trend was observed, because the share of these both plants had been rising steadily, for instance, between 1996 and 2002 maize acreage increased of 505\% (about 10,000 ha). As for maize cultivation, it continued to intensify due to the use of grain for fodder production. Although in Zachodniopomorskie the share of wheat firstly increased by $53.5 \%$ (56,200 ha), and in Wielkopolskie only slightly decreased by $1,800 \mathrm{ha}$, maintaining the high level $227,300 \mathrm{ha}$, as a matter of fact since 2002 meaning decline was observed.

Concerning other plants, in all provinces synonymous fluctuation in changes trends can be seen. For example, area under rape and turnip rape, especially in the first sub-period, significantly grew, in some cases more than doubled, however, the reason was a very cold winter in 1996, destroying $80 \%$ of crops. But regardless of that, the area was going up. The second type of industrial plants, next to rape, is sugar beet, which share had been fallen down consistently, for what the declining demand of sugar is the explanation. Only in Wielkopolskie the share had increased, what follows the tradition of this plant cultivation here. Over the study period, acreage of potatoes had been declining systematically and again the highest share is connected with Wielkopolskie, the region famous for potatoes cultivation.

The changes of major trends of crop rotation reflect variable demand (driving factor) for specific agricultural commodities, both for consumerist and industrial needs, what in a meaningful way was influenced on the preferable plant cultivation type. Among external factors, society

Table 4. Changes in the sown area of the selected crops in provinces of the North-Western Region prepared on the data from Common Agricultural Census Data, years: 1996, 2002, 2010.

\begin{tabular}{|c|c|c|c|c|c|c|c|}
\hline \multirow{2}{*}{ Crops } & 1996 & 2002 & 2010 & \multicolumn{2}{|c|}{ Changes 1996-2002 } & \multicolumn{2}{|c|}{ Changes 2002-2010 } \\
\hline & \multicolumn{3}{|c|}{ In thousends ha } & In thousends ha & In percent & In thousends ha & In percent \\
\hline \multicolumn{8}{|c|}{ Lubuskie Province } \\
\hline Total sown area & 273.4 & 248.8 & 285.1 & -24.6 & -9.0 & +9.3 & +3.7 \\
\hline Basic cereals & 157.2 & 171.5 & 176.9 & +19.3 & +12.3 & +5.4 & +3.1 \\
\hline Rape and turnip rape & 8.4 & 15.1 & 38.9 & +6.7 & +79.8 & +23.8 & +157.6 \\
\hline Sugar beet & 10.9 & 2.3 & 0.9 & -8.6 & -78.9 & -1.4 & -60.9 \\
\hline Potatoes & 15.5 & 10.6 & 5.4 & -4.9 & -31.6 & -5.2 & -49.1 \\
\hline \multicolumn{8}{|c|}{ Wielkopolskie Province } \\
\hline Total sown area & 1516.3 & 1458.2 & 1479.3 & -58.1 & -3.8 & +21.1 & +1.5 \\
\hline Basic cereals & 945.5 & 891.6 & 870.4 & -53.9 & -5.7 & -21.2 & -2.4 \\
\hline Rape and turnip rape & 18.4 & 64.8 & 138.2 & +46.4 & +252.2 & +73.4 & +113.3 \\
\hline Sugar beet & 37.8 & 54.0 & 42.8 & +16.2 & +42.9 & -11.2 & -20.7 \\
\hline Potatoes & 113.5 & 71.5 & 40.0 & -42.0 & -37.0 & -31.5 & -44.1 \\
\hline \multicolumn{8}{|c|}{ Zachodniopomorskie Province } \\
\hline Total sown area & 672.8 & 603.9 & 668.2 & -68.9 & -10.2 & +64.3 & +10.6 \\
\hline Basic cereals & 501.3 & 436.1 & 393.8 & -65.2 & -13 & -42.3 & -9.7 \\
\hline Rape and turnip rape & 29.1 & 66.2 & 116.5 & +37.1 & +127.5 & +50.3 & 76.0 \\
\hline Sugar beet & 24.5 & 13.6 & 12.1 & -10.9 & -44.5 & -1.5 & -11.0 \\
\hline Potatoes & 36.6 & 23.5 & 15.1 & -13.1 & -35.8 & -8.4 & -35.7 \\
\hline
\end{tabular}


demand of certain commodities (social factor) stands out from other. Also important are prescribing agricultural policy objectives (political and economic factors). And finally, it is farmers reaction that was manifested in relation to production profitability (economic factor). In this case, both ever-changing consumer preferences and frequent rebuilding of agricultural policy guidelines, are very important obstacles making difficulties in prediction of dominant direction of crops type cultivation in the nearest future.

Monitoring above described trends at the landscape scale, it turned out that market oriented holdings had greater flexibility to plant production reorientation and thanks to it they were able to faster response to external stimulants. In contrast, self-sufficient family holdings, livestock husbandry and crop cultivation conducting, were not capable of so rapid production retraining. Moreover, it should be emphasized that among natural obstacles of smooth transition the soil quality is the most important one. For instance, wheat and sugar beets require good soil, so even if the farmers would be willing to extend of these plants cultivation, going up against the increasing demand, it is not possible.

Additionally, it should be noted that the direct crop impact is visible by landscape physiognomy changing during the growing season, yet it is just a slightly way of landscape pattern modification. However, cultivation can really affect landscape diversity what is especially seen when policulture rotation system is replaced with intensively used monoculture, which could destroy land heterogeneity. Moreover, simplifying landscape pattern can accelerate the intensification of agrarian production, where industrial plants (especially rape, turnip rape and sugar beet) play particular important roles, as well as intensive cereals (mainly wheat and maize). Besides, usually these plants are cultivated within farmland characterized by higher intensity of market agricultural output.

\section{Conclusions}

The results of study on changes of the agricultural landscape pattern in the North-Western Region were presented above. It should be kept in mind that only some examples of landscape modification were discussed here, however, there is no doubt that man-induced activities had significantly modeled the agrarian space.

Political, economic and social driving forces, as the most affecting, were recognized. Among them, directly and indirectly non-natural factors were distinguished as well as strong interaction between them was proved. As for foreseeable forthcoming tendencies, undoubtedly all mentioned in the paper will put an increasing pressure on landscape changes, however, precise prediction of its pace and intensity is difficult to determine.

By considering the cause-effect relationship between landscape pattern and human influence, there is a potential threat of durability and stability of maintenance of the agricultural landscape structure. This is because of the economic benefits resulting from the productivity increase that not always is favorable for environment.

The results of this study provides a starting point for further analysis, where the aim will be to determine scenarios of changes of the agricultural landscape pattern, with a focus on transformation at the landscape level.

\section{References}

Antrop M. \& VAn Eetvelde V., 2008. Mechanisms in recent landscape transformation. WIT Transactiones on the Build Environment, 100, WIT Press, DOI: 10.24.2495/ GEO080181.

BAŃSKI J. \& CZAPIEWSKI K.Ł., 2007. Diagnoza zróżnicowania wybranych elementów struktury przestrzennej oddziałujacych na gospodarke rolna w skali regionu (Diagnosis of differentiation of selected elements affecting the spatial structure of agricultural economy at the regional level). Diagnoza PAN, IGiPZ im. ST. Leszczyńskiego, Warszawa.

Brandt J., Primdahl J. \& Reenberg A., 1999. Rural land-use and landscape dynamics - analyzing of driving forces in space and time. In: Brandt J. (ed.), Rural land-use and landscape dynamics: analysis of driving forces in space and time. Unesco, Paris: 81-102.

CZAPIEWSKA CZ., 2003. Historyczne uwarunkowania rozwoju rolnictwa uspołecznionego na Pomorzu Środkowym (Historical conditions of socialized agriculture development in the Central Pomerania). Stupskie Prace Geograficzne, 1: 51-61.

KLIJN J.A., 2006. Driving forces behind landscape transformation in Europe, from a conceptual approach to policy options. Wageningen UR, the Netherlands: 201-218. 
KoŁodzIEJCZAK A., 2010. Modele rolnictwa a zróżnicowanie przestrzenne sposobów gospodarowania w rolnictwie polskim (Agricultural models and spatial differences in the farming system in Poland). Wydawnictwo Naukowe UAM, Poznań.

Local Data Bank (on-line -http://www.stat.gov.pl/bdl; 10.06.2012).

Marcucci D.J., 2000. Landscape history as a planning tool. Landscape Urban Planning, 49: 67-81.

MARKUSzEWSKA I., 2012. Wpływ czynników pozaprzyrodniczych na zmiany struktury krajobrazu rolniczego Regionu Północno-Zachodniego w ostatnim dwudziestoleciu (The influence of non-natural factors on changes in agricultural landscape structure in the North-Western Region over the last two decades). Badania Fizjograficzne, seria A, 61: 121-137.

NAveH Z. \& Lieberman A.S., 1984. Landscape Ecology: Theory and Application. Springer, New York.

Nilsson H., 2004. What are the possible influences affecting the future environmental agricultural policy in the European Union? An investigation into the main factors. Journal of Cleaner Production, 12: 461-468.

Program Rozwoju Obszarów Wiejskich na lata 2007-2013 (Programme of Rural Areas Development in 2007-2013), 2010. Ministerstwo Rolnictwa i Rozwoju Wsi, Warszawa (online - http://www.minrol.gov.pl/eng/content/view/ full/18575)

Reger B., Otte A. \& Waldhardt R., 2007. Identifying patterns of land-cover change and their physical attributes in a marginal European landscape. Landscape and Urban Planning, 81: 104-113.
RYSZKOWSKI L., 2002. Landscape ecology in agroecosystem management. CRC Press Inc.

Schaller N., Lazrak E.G., Martin P., Mari J.F., Aubry CH. \& Benoit M., 2012. Combining farmers' decision rules and landscape stochastic regularities for landscape modeling. Landscape Ecology, 27: 433-446.

Statistical Yearbook of Agriculture, 2011. GUS, Warszawa.

Strategia rozwoju obszarów obszarów wiejskich i rolnictwa na lata 2007-2013 z elementami prognozy do roku 2020 (Strategy of Rural and Agriculture Areas Development in 2007-2013 with prognosis up to 2020), 2005. Ministerstwo Rolnictwa i Rozwoju Wsi, Warszawa (on-line - http://www.funduszestrukturalne.gov.pl/informator/npr2/dokumenty strategiczne/rolnictwo.pdf).

Ustawa z dnia 26 marca 1982 r. o scalaniu i wymianie gruntów (Dz.U. z 2003 r. nr 178, poz. 1749 z późn. zm.). Act on Land Consolidation and Exchange of 26 March 1982 (Dz.U. of 2003 No. 178, item 1749).

Vos W. \& MeEKes H., 1999. Trends in European cultural landscape development: perspectives for a sustainable future. Landscape and Urban Planning, 46: 3-14.

WierzchowsKi M., 2007. Przestrzenne, ekonomiczne i społeczne problemy scalania $i$ wymiany gruntów (Spatial, economic and social issues of land consolidation and exchange). IRM, Kraków.

Woch F., 2006. Perspektywy zmian strukturalnych na obszarach wiejskich (The perspectives of structural changes in the rural areas). In: Woch F. (ed.), Kompleksowe scalanie gruntów ornych i leśnych oraz jego wptyw na środowisko. Materiały Szkoleniowe, 29: 5-22. IUNiG, PIB, Puławy. 